\title{
Study of the inflammatory process induced by injection of carrageenan or formalin in the rat temporomandibular joint
}

\section{Estudo do processo inflamatório induzido pela injeção de carragenina ou de formalina na articulação temporomandibular de ratos}

\author{
Alan Cruvinel Goulart* \\ Francisco Antônio dos Santos Correia** \\ Suzana Cantanhede Orsini Machado de Sousa*** \\ João Gualberto de Cerqueira Luz**
}

\begin{abstract}
The aim of this study was to evaluate the effects of the injection of two phlogistic agents, carrageenan and formalin, in the rat TMJ, and the inflammatory process induced by these substances. In this study, a total of 45 adult rats were distributed in two experimental groups and a control group. The animals were sacrificed after three hours, 24 hours, three days, seven days, and 15 days after a single injection of each substance. Histological data initially demonstrated an inflammatory process represented by acute infiltration, which later became mixed, and finally chronic in both experimental groups. Hyperplasia of the synovial membrane was observed after three days, being intense at seven days, and present after 15 days only in the formalin group. Local saline injection in the control group caused no inflammatory reaction. It was concluded that a single local injection of carrageenan or formalin was enough to induce inflammatory reaction in the TMJ and periarticular soft tissues, and that the resulting processes were similar, but more persistent in the formalin group.
\end{abstract}

DESCRIPTORS: Temporomandibular joint; Inflammation; Carrageenan, adverse effects; Formalin, adverse effects.

RESUMO: O objetivo deste trabalho foi avaliar os efeitos da injeção de dois agentes flogísticos, ou seja, carragenina ou formalina, na ATM do rato, e a evolução do quadro inflamatório provocado por essas substâncias. Foram utilizados 45 ratos, divididos em dois grupos experimentais e um grupo controle. Os animais foram sacrificados em lotes de três de cada grupo após três horas, 24 horas, três dias, sete dias e 15 dias da injeção. Histologicamente a reação inflamatória em ambos os grupos experimentais iniciou-se com infiltrado inflamatório agudo, tornando-se misto e depois crônico. Sinais de hiperplasia da membrana sinovial foram observados aos três dias, intensos aos sete dias, estando presentes aos 15 dias somente no grupo da formalina. A injeção de solução salina (grupo controle) não provocou reação inflamatória. No presente trabalho foi concluído que uma injeção local única na região da ATM de carragenina ou de formalina foi suficiente para induzir reação inflamatória na articulação e nos tecidos moles periarticulares. As reações inflamatórias resultantes da injeção desses agentes flogísticos foram semelhantes, mas o grupo da formalina mostrou infiltrado inflamatório mais persistente.

DESCRITORES: Articulação temporomandibular; Inflamação; Carragenina, efeitos adversos; Formalina, efeitos adversos.

\section{INTRODUCTION}

Disorders of the temporomandibular joint (TMJ) frequently present an inflammatory component ${ }^{2}$. However, an understanding of the pathogenesis of inflammation in the TMJ has been based on data from other synovial joints ${ }^{18}$. A few experimental studies have evaluated only the immediate events of the inflammatory process in the $\mathrm{TMJ}^{8}$.
Special features of the TMJ, such as its dense fibrous tissue covering, may influence its response as a synovial joint ${ }^{16,19}$. Also, concentrations of some inflammatory substances in the TMJ differ from those in other joints, probably due to the denser innervations in the former ${ }^{7}$. A satisfactory orofacial model should permit the study of inflammation

\footnotetext{
* M.S. Graduate Student.

** Associate Professors, Department of Maxillofacial Surgery, Prosthodontics and Traumatology; ***Associate Professor, Department of Oral Pathology - School of Dentistry, University of São Paulo.
} 
Goulart AC, Correia FAS, Sousa SCOM, Luz JGC. Study of the inflammatory process induced by injection of carrageenan or formalin in the rat temporomandibular joint. Braz Oral Res 2005;19(2):100-5.

in general, as well as of mechanisms that may be specific to TMJ tissues ${ }^{5}$.

The purpose of the present study was to evaluate an experimental model in an attempt to analyze the effects of the injection of two phlogistic agents carrageenan and formalin - in the rat TMJ.

\section{MATERIALS AND METHODS}

The study animals were 45 three-month-old female Wistar rats weighing 190 to $250 \mathrm{~g}$. They were housed three per cage at $23^{\circ} \mathrm{C}$ in a $12 \mathrm{~h}$ light/ dark cycle, and received an ordinary diet of rodent feed (Labina, Agribrands Purina, Paulinia, Brazil) and water. The study was approved by the local research ethics committee.

The animals were anaesthetized by an intraperitoneal injection of xylazine hydrochloride (Rompum, Bayer, Porto Alegre, Brazil), 10 mg/kg of body weight and ketamine hydrochloride (Ketalar, Parke-Davis, Rio de Janeiro, Brazil), 25 mg/kg of body weight. The right preauricular area was shaved and cleansed with a povidone-iodine solution (Riodeíne, Rioquímica, São José do Rio Preto, Brazil). The animals were distributed in two experimental groups and a control group with 15 rats each. The rats received a local injection in the right TMJ of $0.02 \mathrm{ml}$ of either $1 \%$ carrageenan (Sigma-Aldrich, St. Louis, MO, USA) in saline solution (carrageenan group), $5 \%$ buffered formalin solution (Laboratório Fórmula e Ação, São Paulo, Brazil) (formalin group), or $0.9 \%$ saline solution (Áster Produtos Médicos, Sorocaba, Brazil) (control group). Each solution was introduced by placing the tip of a 29-gauge needle (Becton Dickison, Curitiba, Brazil) just posteriorly to the zygomatic process of the temporal bone. The needle tip was then moved medioanteriorly towards the superior joint space.

The animals were sacrificed three hours, 24 hours, three days, seven days, and 15 days after the local injection of the solutions. Their heads were removed and fixed in 10\% formalin (Quimex, Cotia, Brazil). The specimens were decalcified in 20\% formic acid (Merck, Darmstadt, Germany) and coronal sections were obtained. Seven $\mu \mathrm{m}$ thick sections of the right TMJ were cut and stained with hematoxylin and eosin (Merck, Darmstadt, Germany). Injured and control sites were studied at the same magnification. The aim was to describe cellular infiltration and its type, periarticular soft tissue oedema, exudate extravasation, congested vessels, alterations in the joint capsule, synovial lining hyperplasia, and changes in the articular surfaces.

\section{RESULTS}

The animals made a recovery after the phlogistic agent injection. Food and water intakes were considered normal 24 hours after the injection, and the animals did not experience any weight loss. Edema was macroscopically observed on the lateral region of the face of the animals of the experimental groups in the first 24 hours. The histopathological findings are presented according to the substance and sacrifice time.

\section{Carrageenan group \\ Three hours}

Moderate neutrophilic exudation in the condylar neck region was observed, as well as edema and fibrin-hemorrhagic exudate. Lymphocytes were seen in the lumen of congested blood vessels (Figure 1A).

\section{Twenty-four hours}

Intense inflammatory exudation and edema were observed in the condylar neck region. Acute inflammatory cells extended among adjacent muscular fibers, dissociating them; an inflammatory process was also present in the joint capsule, with congested blood vessels and neutrophilic subsynovial exudation (Figure 1B).

\section{Three days}

Mixed inflammatory infiltration was observed in the condylar neck region, extending among dissociated muscular fibers. Also, serofibrinous exudate and congested blood vessels could be seen in the condylar neck. In the articular capsule, mild subsynovial mononuclear infiltration was observed, as well as a slight proliferation of the synovial lining. Numerous inflammatory cells could be seen in the joint space (Figure 1C).

\section{Seven days}

Mild mononuclear infiltration in the condylar neck region and among muscular fibers in a restricted region near the condyle was observed. A few congested blood vessels were noticed. Marked proliferation of the synovial lining was present, and villous hyperplasia could be observed in some 
Goulart AC, Correia FAS, Sousa SCOM, Luz JGC. Study of the inflammatory process induced by injection of carrageenan or formalin in the rat temporomandibular joint. Braz Oral Res 2005;19(2):100-5.
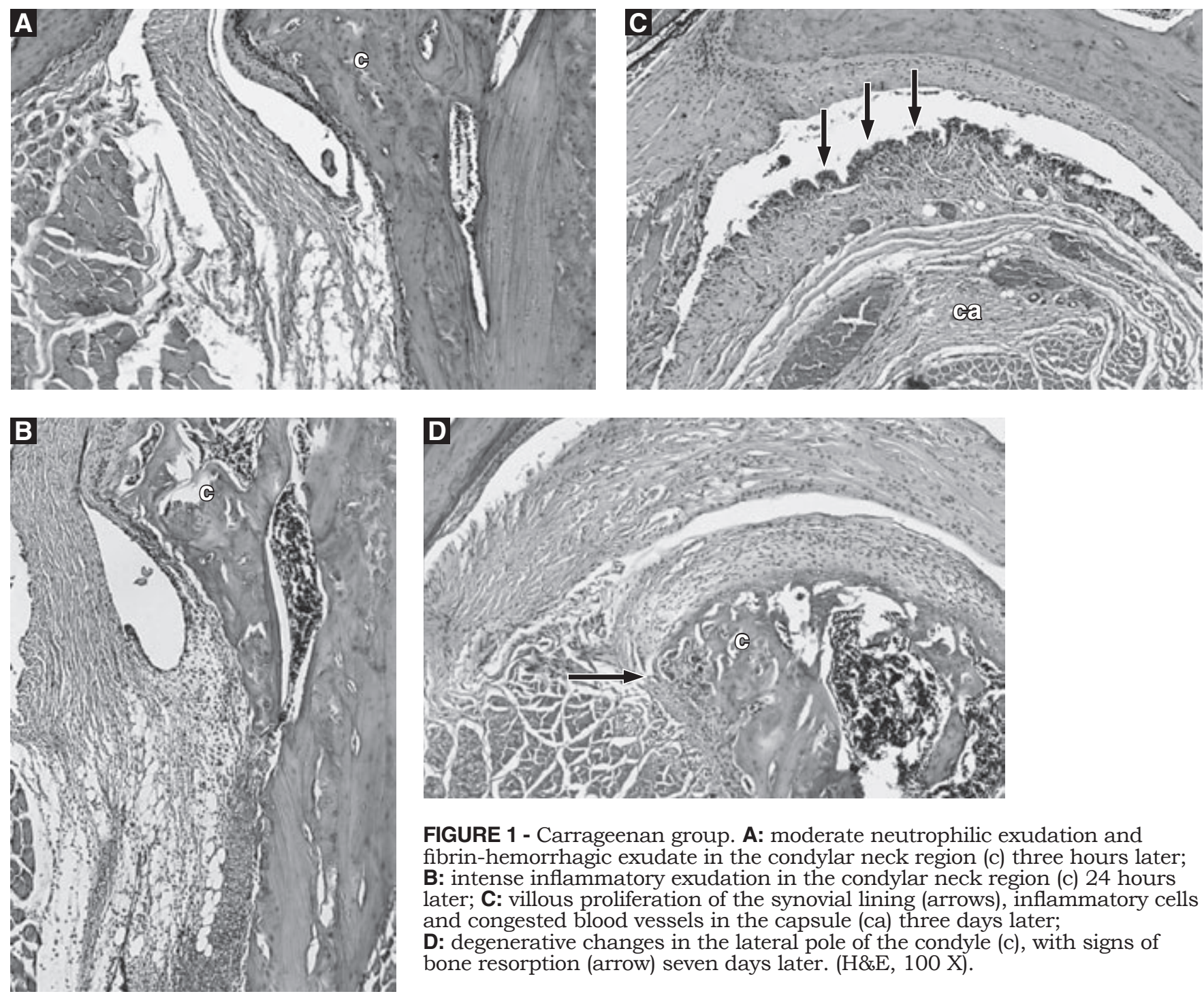

FIGURE 1 - Carrageenan group. A: moderate neutrophilic exudation and fibrin-hemorrhagic exudate in the condylar neck region (c) three hours later; B: intense inflammatory exudation in the condylar neck region (c) 24 hours later; C: villous proliferation of the synovial lining (arrows), inflammatory cells and congested blood vessels in the capsule (ca) three days later;

D: degenerative changes in the lateral pole of the condyle (c), with signs of bone resorption (arrow) seven days later. (H\&E, $100 \mathrm{X})$.

areas of the joint. One specimen showed degenerative changes in the lateral pole of the condyle, with signs of bone resorption (Figure 1D).

\section{Fifteen days}

None of the specimens showed any signs of inflammation or changes in the articular tissues.

\section{Formalin group}

\section{Three hours}

Edema and mild neutrophilic exudation were observed in the condylar neck region, extending along the muscular fibers around the joint (Figure $2 \mathrm{~A}$ ).

\section{Twenty-four hours}

Marked inflammatory exudation and edema in the condylar neck region were observed. Cell infiltration was of the mixed type and scattered among adjacent muscular fibers, dissociating them. In the same region, serofibrinous-hemorrhagic exudate was observed. The inflammatory process in the joint capsule showed a great number of congested blood vessels and subsynovial inflammatory infiltration, while the synovium appeared to be normal.

\section{Three days}

Predominantly mononuclear cellular infiltration was seen in the condylar neck region, extend- 
Goulart AC, Correia FAS, Sousa SCOM, Luz JGC. Study of the inflammatory process induced by injection of carrageenan or formalin in the rat temporomandibular joint. Braz Oral Res 2005;19(2):100-5.
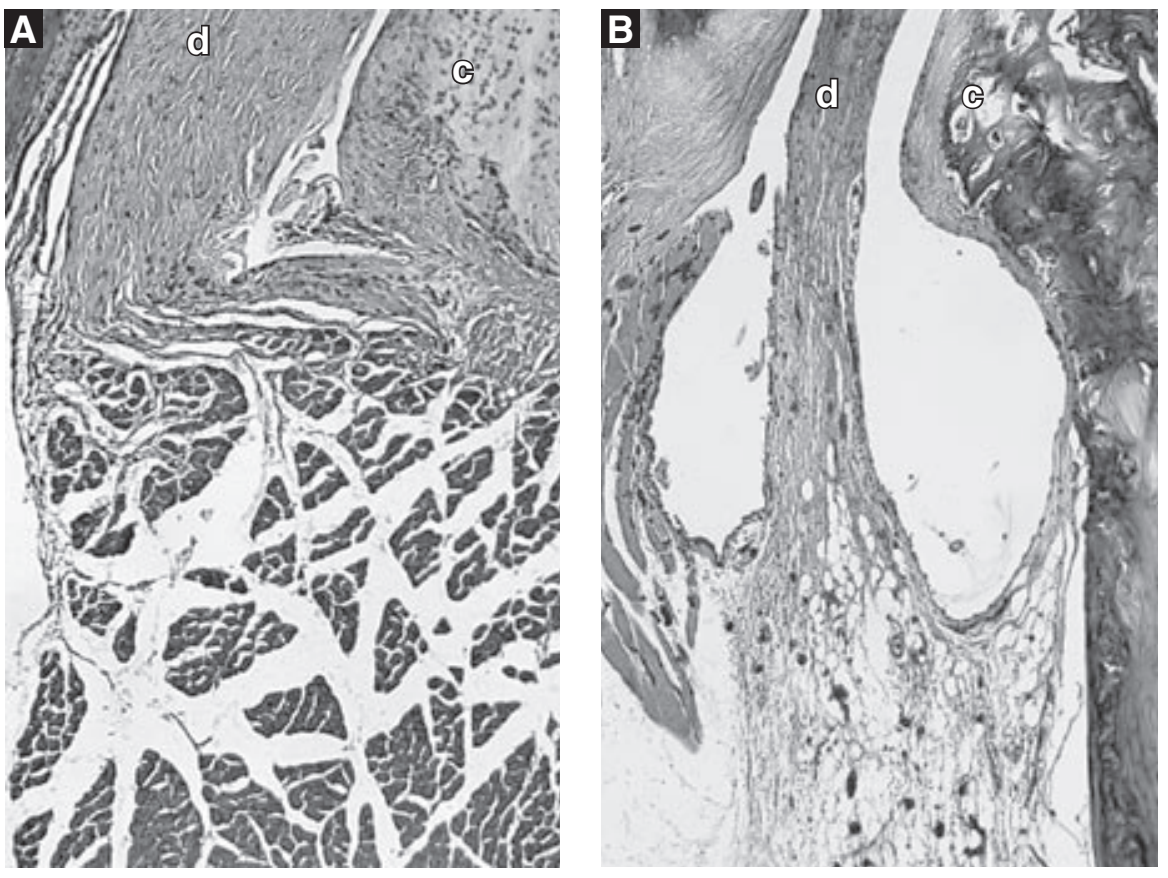

FIGURE 2 - Formalin group. A: mild neutrophilic exudation extending along muscular fibers three hours later; B: serofibrinous-hemorrhagic exudate, congested blood vessels and cellular infiltration in the condylar neck region three days later. $\mathrm{c}=$ condyle, $\mathrm{d}=$ articular disc $(\mathrm{H} \& \mathrm{E}$, $100 \mathrm{X})$. (Continued on page 103).

ing among dissociated muscular fibers. Also, serofibrinous-hemorrhagic exudate and congested blood vessels could be seen in the condylar neck. Subsynovial mononuclear cellular infiltration and congested blood vessels were observed in the articular capsule. Discrete hyperplasia of the synovial lining could be seen (Figure 2B).

\section{Seven days}

Intense inflammatory infiltration, predominantly mononuclear, was observed around the articular capsule, but it was only mild among muscular fibers. Serofibrinous exudate and congested blood vessels could be seen in the periarticular region. Marked hyperplasia of the synovial lining was present, and villous changes could be observed. One animal showed hyalinization and thickening of the condylar articular surface, with absence of the proliferative zone and atrophy of the fibrocartilage (Figures 2C and 2D).

\section{Fifteen days}

Mild mononuclear cellular infiltration dispersed among collagen fibers in the condylar neck region was observed. Some congested blood vessels were present and villous changes in the synovium were still evident (Figure 2E).

\section{Control group}

The injection of normal saline solution did not produce changes at any sacrifice time. The articular tissues presented characteristics of normality (Figure 3).

\section{DISCUSSION}

The present study showed that a single local injection of carrageenan or formalin results in an inflammatory reaction in the TMJ and periarticular tissues, with hyperplasia of the synovial membrane. The results were similar, although more persistent when formalin was used. Formalin has been used as a classic model to produce experimental inflammation ${ }^{11,20}$. Carrageenan can induce a highly reproducible local antigenic inflammatory response ${ }^{17}$. Carrageenan has been widely used to evaluate the anti-inflammatory effect of certain drugs ${ }^{4,11,15}$.

Edema was the initial finding after the injection of either substance. A similar response has been reported with the use of these substances in the rat footpad or $\mathrm{knee}^{4,17}$. In our experiment, edema was histologically observed between three and 24 hours, and practically disappeared after three days. This is in accordance with the findings reported in the related literature, which have shown intense edema after three hours, mild edema within three days and no edema at day seven ${ }^{14}$. 
Goulart AC, Correia FAS, Sousa SCOM, Luz JGC. Study of the inflammatory process induced by injection of carrageenan or formalin in the rat temporomandibular joint. Braz Oral Res 2005;19(2):100-5.
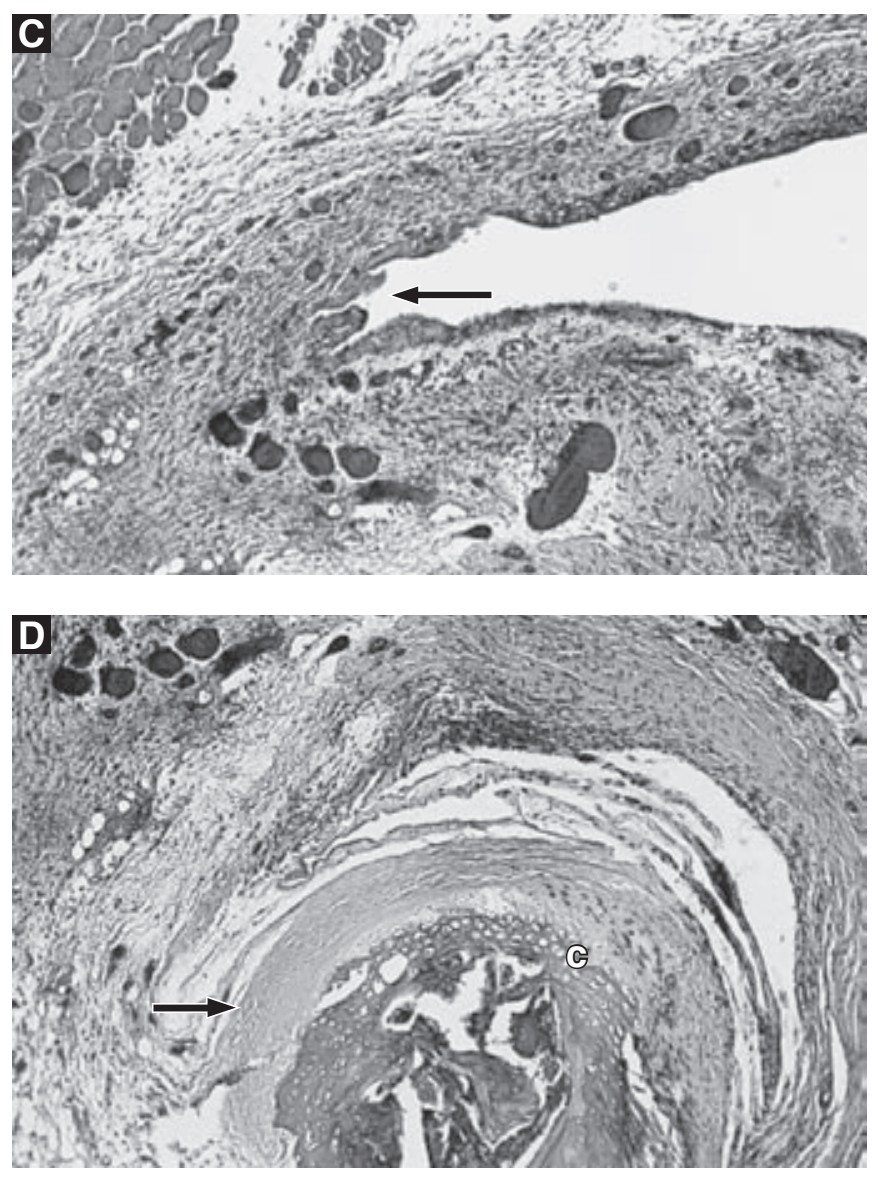

Edema induced by carrageenan injection is gradual, measurable after one hour, maximum after three hours and lasts for several days ${ }^{3}$. Our results also showed that cellular migration caused by carrageenan injection was moderate after three hours, but more intense than that caused by formalin injection. After 24 hours, both substances induced an intense inflammatory infiltration, which later became mild in the condylar neck region in the carrageenan group, but remained intense around the capsule in the formalin group, extending among muscular fibers in both groups. After 15 days, a mild inflammatory infiltration dispersed in the condylar neck region was observed only in the formalin group. Similar findings have been reported after carrageenan injection in the rat footpad ${ }^{4}$.

Fibrinous-hemorrhagic/serofibrinous exudate was initially observed in both groups, being present for up to seven days. No exudate was observed after 15 days. Superficial fibrin deposition in synovitis cases has also been observed ${ }^{13}$. Inflammatory cells enmeshed in fibrin webs have been demonstrated 24 hours after PLA injection in the

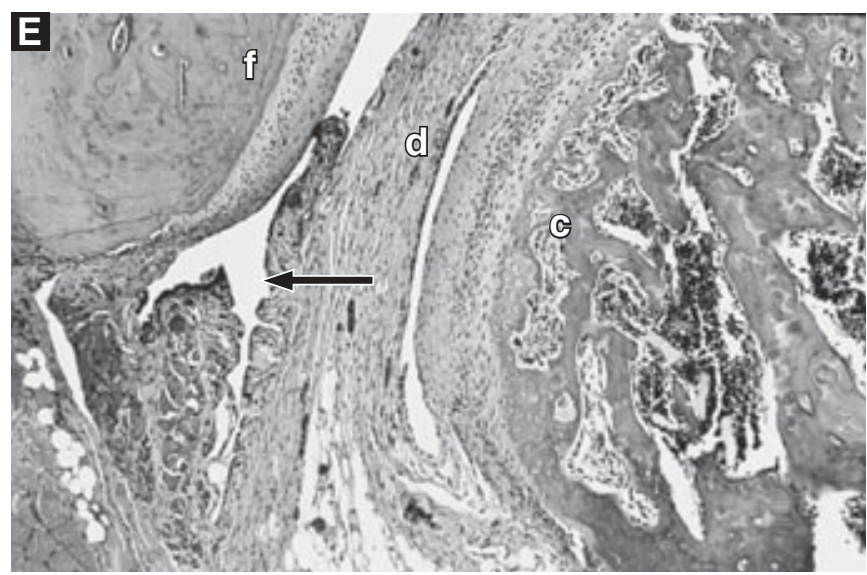

FIGURE 2 (continued) - Formalin group. C: hyperplasia of the synovial lining with villous changes (arrow) seven days later; D: hyalinization and thickening of the condylar articular surface (arrow), inflammatory reaction in the articular capsule, with subsynovial cellular infiltration and congested blood vessels seven days later; E: villous changes (arrow) and thickening of the synovial lining 15 days later. $\mathrm{c}=$ condyle, $\mathrm{d}=$ articular disc, $\mathrm{f}=$ articular fossa $(\mathrm{H} \& \mathrm{E}, 100 \mathrm{X})$.

rat knee joint ${ }^{21}$. Inflammatory alterations in the joint capsule, such as the presence of congested blood vessels and subsynovial inflammatory infiltration, were observed in both experimental groups between 24 hours and three days. Similar results

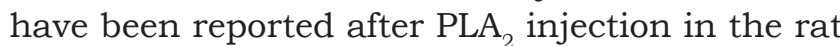
knee, with the higher number of congested blood vessels occurring after 24 hours, with maximum cellular infiltration observed after 96 hours $^{21}$.

Hyperplasia of the synovial lining was noticed in both experimental groups after three days, when mild cellular proliferation was present. It was intense after seven days, when it was possible to identify villous areas. However, after 15 days, it was present only in the formalin group. A histologic study of the rat knee joint has shown that 24 hours after injection of the irritating agent the synovial lining became markedly folded, and hyperplasia of the synovium was seen after 48 hours ${ }^{21}$. Similar findings have been reported when synovitis was induced by trauma to the rat TMJ, and fibrous synovial thickening was noticeable 10 weeks after trauma ${ }^{12}$. In addition, intense hyperplasia of the 
Goulart AC, Correia FAS, Sousa SCOM, Luz JGC. Study of the inflammatory process induced by injection of carrageenan or formalin in the rat temporomandibular joint. Braz Oral Res 2005;19(2):100-5.

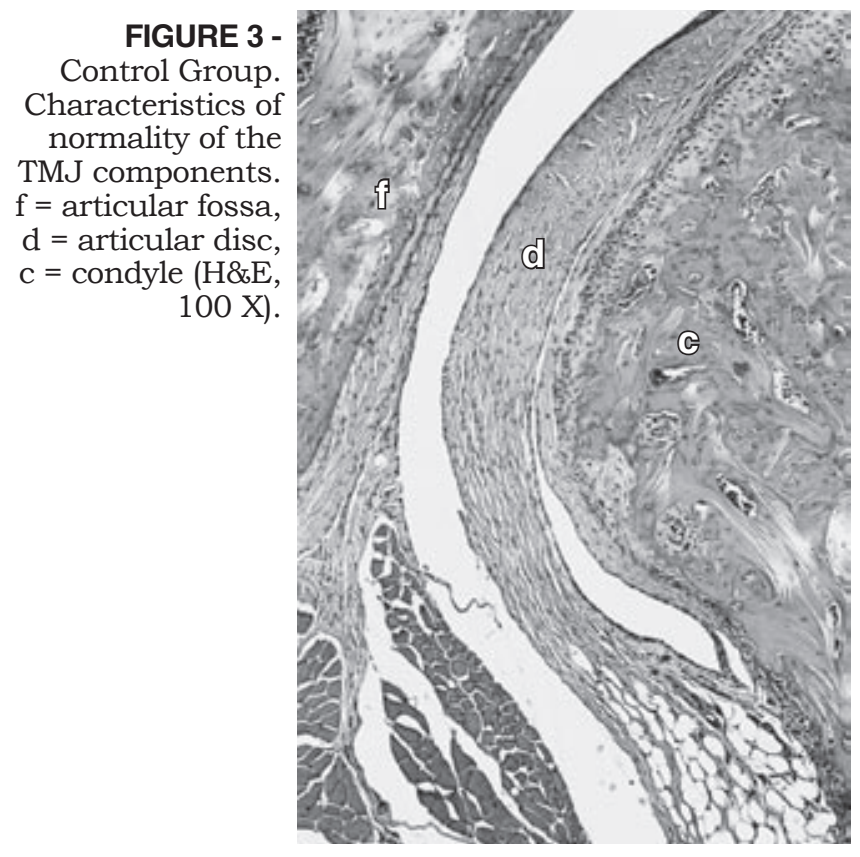

synovial membrane occurred when anterior disc displacement was induced in the rabbit TMJ, and the hyperplastic synovial cells were present at six weeks postoperatively ${ }^{1}$. It has been shown that the synovial tissue contains cells that are potentially angiogenic. Vessels from the peripheral capillary plexus and synovial membrane cells proliferate to provide the vascular origin for the connective tissue healing of the lesion ${ }^{6}$.

Signs of degenerative alterations were observed on the condyle of one specimen from each group. In the carrageenan group there was a case of partial resorption of the condyle, while in the formalin group there was a case with hyalinization and thickening of the articular surface. The

\section{REFERENCES}

1. Ali AM, Sharawy MM. Histopathological changes in rabbit craniomandibular joint associated with experimentally induced anterior disk displacement. J Oral Pathol Med 1994;23:364-74.

2. Carleson J, Alstergren P, Appelgren A, Appelgren B, Kopp S, Lunderberg $\mathrm{T}$, et al. A model for the study of experimentally induced temporomandibular arthritis in rats: the effect of human recombinant interleukin- $1 \alpha$ on neuropeptide-like immunoreactivity. J Orofac Pain 1996;10:9-13.

3. Carvalho JCL, Sertié JAA, Barbosa MVJ, Patrício KCM, Caputo LRG, Sarti SJ, et al. Anti-inflammatory activity of the crude extract from the fruits of Pterodon emarginatus. J Ethnopharmacol 1999;64:127-33. possibility of substances initially causing necrosis followed by degenerative alterations should be considered. However, such alterations occurred in only one specimen of each group of substance, which suggests a need for further studies. Similar findings, albeit more thorough, have been reported after indirect trauma in the rat $\mathrm{TMJ}^{10}$. No similar findings with carrageenan or formalin have been reported in the related literature, probably due to the short periods of observation. On the other hand, some authors have reported that alterations such as bone erosion and loss of cartilage may occur in chronic inflammation, as caused by rheumatoid arthritis due to proliferative invasion of the synovial lining and the formation of pannus ${ }^{9,18,19}$.

\section{CONCLUSION}

Both phlogistic agents used in this experiment were able to induce a local inflammatory reaction after only a single injection of each substance. However, despite the similarity between the inflammatory reactions caused by carrageenan or by formalin, including intensity and kind of cell infiltration, formalin induced more persistent inflammation. Thus, in this study, it was also possible to verify the response of the TMJ to these aggressive agents, which included initial acute inflammatory infiltration followed by chronic infiltration. Moreover, the response resulted in cellular proliferation of the synovial lining, hyperplastic and villous areas being observed, and here the reaction to formalin was again more persistent. This model may therefore be useful in further studies of the inflammatory response of the TMJ and make the development of new anti-inflammatory treatments possible.

4. Gualillo O, Eiras S, Lago F, Diéguez C, Casanueva FF. Elevated serum leptin concentrations induced by experimental acute inflammation. Life Sci 2000;67:2433-41.

5. Haas DA, Nakanishi RE, Macmillan RE, Jordan RC, Hu JW. Development of an orofacial model of acute inflammation in the rat. Arch Oral Biol 1992;37:417-22.

6. Helmy ED, Bays R, Sharawy MM. Histopathological study of human TMJ perforated discs with emphasis on synovial membrane response. J Oral Maxillofac Surg 1989;47:1048-52.

7. Holmlund A, Ekblom A, Hansson P, Lind J, Lundeberg $\mathrm{T}$, Theodorsson E. Concentrations of neuropeptides substance $\mathrm{P}$, neurokinin A, calcitonin gene-related peptide, neuropeptide $\mathrm{Y}$ and vasoactive intestinal polypeptide in synovial fluid of the human temporomandibular joint: a 
Goulart AC, Correia FAS, Sousa SCOM, Luz JGC. Study of the inflammatory process induced by injection of carrageenan or formalin in the rat temporomandibular joint. Braz Oral Res 2005;19(2):100-5.

correlation with symptoms, signs and arthroscopic findings. Int J Oral Maxillofac Surg 1996;20:228-31.

8. Hutchins B, Spears R, Hinton R, Harper RP. Calcitonin gene-related peptide and substance $\mathrm{P}$ immunoreactivity in rat trigeminal ganglia and brainstem following adjuvantinduced inflammation of the temporomandibular joint. Arch Oral Biol 2000;45:335-45.

9. Kapila S, Lee C, Tavakkoli JMR, Miller AJ, Richards DW. Development and histologic characterization of an animal model of antigen-induced arthritis of the juvenile rabbit temporomandibular joint. J Dent Res 1995;74:1870-9.

10. Luz JGC, Jaeger RG, Araujo VC, Rezende JRV. The effect of indirect trauma on the rat temporomandibular joint. Int J Oral Maxillofac Surg 1991;20:48-52.

11. Mazzari S, Canella R, Petrelli L, Marcolongo G, Leon A. N-(2-Hydroxyethyl) hexadecanamide is orally active in reducing edema formation and inflammatory hyperalgesia by down-modulating mast cell activation. Eur J Pharmacol 1996;300:227-36.

12. Muto T, Kawakami J, Kanazawa M, Yajima T. Histologic study of synovitis induced by trauma to the rat temporomandibular joint. Oral Surg Oral Med Oral Pathol 1998;86:534-40.

13. Ostergaard M, Stoltenberg M, Lovgreen-Nielsen $P$, Volck B, Sonne-Holm S, Lorenzen I. Quantification of synovitis by MRI: correlation between dynamic and static gadolinium-enhanced magnetic resonance imaging and microscopic and macroscopic signs of synovial inflammation. Magn Reson Imaging 1998;16:743-54.
14. Perrot S, Guilbaud G, Kayser V. Effects of intraplantar morphine on paw edema and pain-related behaviour in a rat model of repeated acute inflammation. Pain 1999;83:249-57.

15. Singh GB, Atal CK. Pharmacology of an extract of Salai guggal ex-Broswellia serrata, a new non-steroidal anti-inflammatory agent. Agents Actions 1986;18(3-4):407-12.

16. Stegenga B, Bont LGM, Boering G. Osteoarthrosis as the cause of craniomandibular pain and dysfunction: a unifying concept. J Oral Maxillofac Surg 1989;47:249-56.

17. Stringer KA, Bose SK, Mccord JM. Antiinflammatory activity of tissue plasminogen activator in the carrageenan rat footpad model. Free Radic Biol Med 1997;22:985-8.

18. Tominaga K, Alstergren $\mathrm{P}$, Kurita $\mathrm{P}$, Kopp S. Clinical course of antigen-induced arthritis model in the rabbit temporomandibular joint. J Oral Pathol Med 1999;28:268-73.

19. Tominaga K, Alstergren P, Kurita H, Kopp S. Serotonin in an antigen-induced arthritis of the rabbit temporomandibular joint. Arch Oral Biol 1999;44:595-601.

20. Yang LC, Marsala M, Orendacova J, Yaksh TL. Knee joint inflammation attenuates spinal FOS expression after unilateral paw formalin injection in rat. Neurosci Lett 1997;225:89-92.

21. Zhang CP, Gopalakrishnakone P. Histopathological studies of the acute inflammation in synovial tissue of rat knee joint following intra-articular injection of PLA2 from Chinese Cobra (Naja naja atra) venom. Toxicon 1999;37:783-99.

Received for publication on Dec 08, 2004

Sent for alterations on Apr 15, 2005

Accepted for publication on Jun 27, 2005 